\title{
Qu'Appelle Valley Hiking Trail
}

by David Green, Regina

The year 1963 was the year of the 50-mile hike, marathon bathtubpushing and other symptoms of a people's self-conscious awakening to certain physical shortcomings.

Though of United States origin, the fads enjoyed parallel popularity in Canada; quite understandably, since we share the American heritage with its strength and its foibles. And among those foibles is a predilection for ease of travel and over-sophistication of the accoutrements of outdoor living. Prince Phillip decried this trait when he accused Canadians of being "soft."

For generations, medical men have called walking "the perfect exercise," yet walking is curiously ignored as a pastime in Saskatchewan. Perhaps not so curiously, for, as Wallace Stegner points out in his book Wolf Willow:

"You don't get out of the wind, but learn to lean and squint against it. You don't escape sky and sun, but wear them in your eyeballs and on your back. You become acutely aware of yourself. The world is very large, the sky even larger, and you are very small. But also the world is flat, empty, nearly abstract, and in its flatness you are a challenging upright thing, as sudden as an exclamation mark, as enigmatic as a question mark.

". . Unless North American tourists discover the beauty of the geometric earth and the enormous sky brimming with weather and learn the passion of loneliness and the mystery of a prairie wind | southern Saskatchewan| is going to have little to work with; it will remain marginal or sub-marginal in its community and cultural life."

True, Stegner's remarks applied specifically to one small Saskatchewan town (Eastend, which he called Whitemud), and he was viewing it from the perspective of an urbane man of letters. (Mr. Stegner is the head of the Creative Writing Centre at Stanford University.) Yet his perception is keen and his con- clusions accurate, at least insofar as the lack of an aesthetic appreciation of the level prairie is concerned.

The open prairie, the treeless plains, do not lend themselves to hiking. But Saskatchewan is provided with one of the most charming hiking areas to be found in North America-the Qu'Appelle Valley, whose softly contoured hills and wooded coulees afford shelter from the incessant winds and the overzealous summer sun.

Personal observation has demonstrated to me the relation between recreational facilities and the population density of an area. In Calgary, for example, I met dozens of individuals who had moved to the foothills city, not because it offered them the best job opportunities or the highest standard of living, but because they were skiing enthusiasts or amateur mountain climbers or ardent eque $\overline{3}-$ trians. Similarly, in Vancouver I found yachting and swimming devotees who had gone there because their avocational interests could best be served in the coastal city. Personally, I believe it would behove Saskatchewan to take advantage of the unique hiking opportunities offered by the valley of the Qu'Appelle.

Europeans are fervent hikers. Youth hostels flourish in every country in Europe, and it is entirely possible that their existence goes a long way toward explaining Prince Phillip's observation that we are not so hardy a people as our European counterparts.

Imagine a trail commencing at the Elbow of the South Saskatchewan River and extending the full length of the Qu'Appelle Valley to the Manitoba border. Along it, at intervals of several miles, simple shelters such as those employed along the Appalachian Trail in the eastern United States-that is, lean-to's with shelves where sleeping-bags can be spread, facilities for cooking, and fresh water.

As a self-guided trail, the route would encompass a good deal of the 
geological, biological and human history of southern Saskatchewan. It would have the added advantage of passing close to, or through, a number of provincial parks and privately-operated resorts.

In areas where hoodlumism or remoteness might pose a problem for the hiker, patrols could be established to insure safety.

Easements would have to be acquired from landholders along the line of march, but the trail could avoid interference with stock and farmers' crops by sticking close to the valley wall. During wet seasons, a portion of the route might be navigable by canoe and some segments would lend themselves well to horseback riding. Even in winter, parts cf the trail might be utilized in the vicinity of skiing resorts, and the number of organizations and school groups who could make use of such a trail for educational or observational purposes is quite substantial.

If sufficient support for such an idea could be found in communities adjacent to, or in the valley, the marking out of the trail could become a co-operative effort, correlated by a central headquarters and perhaps facilitated through some governmental agency.

Such a hostelry system, touchirig as it would upon many of the historic outposts of our early history, would be a suitable 1967 centenary memorial to the pioneers.

Editor's Note: This ideo of a trail in the Qu'Appelle Valley was first proposed and discussed in the Soskotchewon Notural History Society during our Summer Meeting in Fort Qu'Appelle in June, 1962. Although the idea was fovorobly received $i$ believe there has been little further study of the ideo and no mopping of octual trail routes. If you are interested or in a position to help you should write to your society or to your member of Porlioment giving your suggestions and urging the development of such a troil.

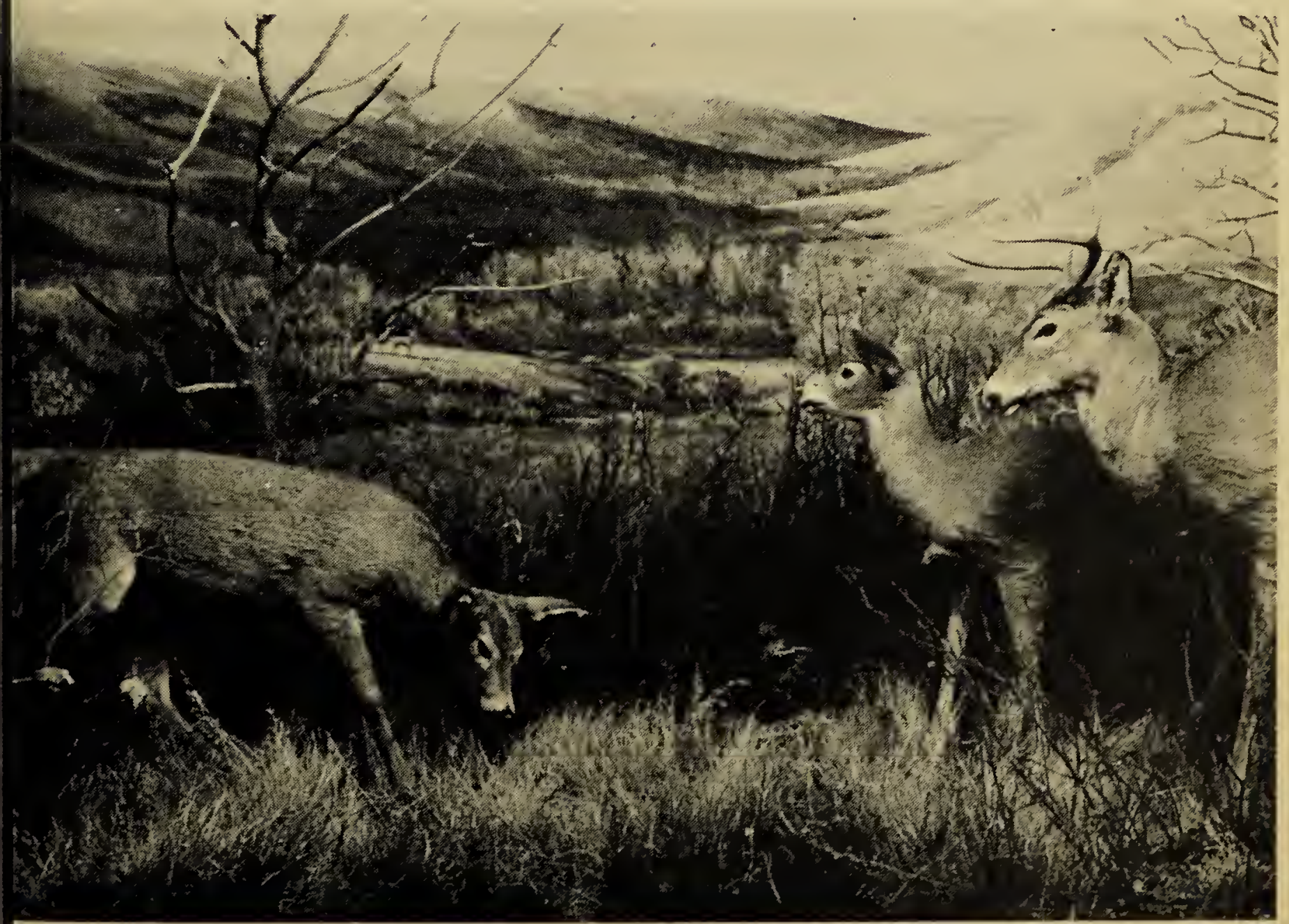

